\title{
AMIODARON SEBAGAI OBAT ANTI ARITMIA DAN PENGARUHNYA TERHADAP FUNGSI TIROID
}

\author{
Starry H. Rampengan
}

\author{
Bagian Ilmu Penyakit Jantung dan Pembuluh Darah \\ Fakultas Kedokteran Universitas Sam Ratulangi Manado \\ Email: starryh_rampengan@yahoo.com
}

\begin{abstract}
Amiodarone is a highly effective anti-arrhythmic agent used in certain arrhythmias from supraventricular tachycardia to life-threatening ventricular tachycardia. Its use is associated with numerous side-effects that could deteriorate a patient's condition. Consequently, a clinician should consider the risks and benefits of amiodarone before initiating the treatment.The thyroid gland is one of the organs affected by amiodarone. Amiodarone and its metabolite desethyl amiodaron induce alterations in thyroid hormone metabolism in the thyroid gland, peripheral tissues, and probably also in the pituitary gland. These actions result in elevations of serum T4 and rT3 concentrations, transient increases in TSH concentrations, and decreases in T3 concentrations. Both hypothyroidism and hyperthyroidism are prone to occur in patients receiving amiodarone. Amiodarone-induced hypothyroidism (AIH) results from the inability of the thyroid to escape from the Wolff-Chaikoff effect and is readily managed by either discontinuation of amiodarone or thyroid hormone replacement. Amiodarone-induced thyrotoxicosis (AIT) may arise from either iodine-induced excessive thyroid hormone synthesis (type I, usually with underlying thyroid abnormality), or destructive thyroiditis with release of preformed hormones (type II, commonly with apparently normal thyroid glands). Therefore, monitoring of thyroid function should be performed in all amiodarone-treated patients to facilitate early diagnosis and treatment of amiodarone-induced thyroid dysfunction.
\end{abstract}

Keywords: amiodarone, thyroid function, side effect, management, monitoring

\begin{abstract}
Abstrak: Amiodaron adalah obat antiaritmia yang cukup efektif dalam menangani beberapa keadaaan aritmia mulai dari supraventrikuler takikardia sampai takikardia ventrikuler yang mengancam kehidupan. Namun penggunaan obat ini ternyata menimbulkan efek samping pada organ lain yang dapat menimbulkan perburukan keadaan pasien. Sehingga, dalam penggunaan amiodaron, klinisi juga harus menimbang keuntungan dan kerugian yang ditimbulkan oleh obat ini. Salah satu organ yang dipengaruhi oleh amiodaron adalah kelenjar tiroid. Amiodaron dan metabolitnya desetil amiodaron memengaruhi hormon tiroid pada kelenjar tiroid, jaringan perifer, dan mungkin pada pituitari. Aksi amiodaron ini menyebabkan peningkatan T4, rT3 dan TSH, namun menurunkan kadar T3. Hipotiroidisme dan tirotoksikosis dapat terjadi pada pasien yang diberi amiodaron. Amiodarone-induced hypothyroidism (AIH) terjadi karena ketidakmampuan tiroid melepaskan diri dari efek Wolff Chaikof, dan dapat ditangani dengan pemberian hormon substitusi T4 atau penghentian amiodaron. Amiodarone-induced thyrotoxicosis (AIT) terjadi karena sintesis hormon tiroid yang berlebihan yang diinduksi oleh iodium (tipe I, biasanya sudah mempunyai kelainan tiroid sebelumnya) atau karena tiroiditis destruktif yang disertai pelepasan hormon tiroid yang telah terbentuk (tipe II, biasanya dengan kelenjar yang normal). Pemantauan fungsi tiroid seharusnya dilakukan pada semua pasien yang diberi amiodaron untuk memfasilitasi diagnosis dan terapi yang dini terjadinya disfungsi tiroid yang diinduksi amiodaron.
\end{abstract}

Kata kunci: amiodaron, fungsi tiroid, efek samping, penanganan, pemantauan 
Amiodaron adalah obat aritmia yang saat ini banyak digunakan pada keadaan aritmia mulai dari atrial fibrilasi paroksismal sampai takiaritmia ventrikuler yang mengancam hidup. Potensi dan kegunaan amiodaron sudah diteliti dalam beberapa uji klinis besar. Hasil studi European Myocardial Infarction Amiodarone Trial (EMIAT) dan Canadian Amiodaron Myocardial Infarction Arrhytmia Trial (CAMIAT) menunjukkan bahwa pemberian amiodaron dapat menurunkan kematian akibat aritmia dan ventrikular fibrilasi (VF) yang diresusitasi setelah kejadian infark jantung. GESICA dan CHF-STAT, uji klinis yang meneliti pemberian amiodaron pada pasien gagal jantung menunjukkan bahwa obat ini aman diberikan pada pasien gagal jantung. Dengan berbagai bukti dari uji klinis ini, penggunaan amiodaron makin meningkat dalam mengatasi aritmia. ${ }^{1,2}$

Penggunaan amiodaron ternyata juga dikaitkan dengan efek samping yang bisa berakibat fatal. Amiodaron dan metabolitnya yang bersifat lipofilik didistribusikan ke berbagai jaringan. Karena ini, efek samping amiodaron dapat melibatkan berbagai organ seperti kulit, mata, hati, paru, saraf dan tiroid. ${ }^{1,3}$

Amiodaron mempunyai beberapa efek terhadap fungsi tiroid bahkan tanpa adanya tirotoksikosis atau hipotiroidisme. Amiodaron dapat meningkatkan kadar tiroksin (T4), reverse triiodothyronine (rT3), thyroid stimulating hormone (TSH), dan menurunkan triiodotironin (T3). Walaupun terjadi perubahan pola hormon tiroid, pasien yang mendapat amiodaron dapat terus berada dalam keadaan eutiroid. Kelainan tiroid, baik tirotoksikosis maupun hipotiroidisme, keduanya dapat menyebabkan perburukan pada pasien yang sudah mengalami aritmia sehingga penting sekali untuk memonitor fungsi tiroid pada mereka yang mendapatkan terapi amiodaron. ${ }^{4-8}$

Pengaruh amiodaron terhadap fungsi tiroid yang meliputi pengaruhnya terhadap metabolisme dan sintesis hormon tiroid, perubahan pola hormon tiroid, dan kelainan tiroid yang diinduksi oleh amiodaron, perlu dipahami dengan baik untuk efisiensi tatalaksana kelainan tiroid akibat amiodaron.

\section{AMIODARON SEBAGAI OBAT ARIT- MIA}

\section{Struktur kimia}

Amiodaron adalah derivat benzofuran yang mengandung dua atom iodium per molekul. Amiodaron mengandung iodium sebanyak $37 \%$ dari beratnya. Sekitar $10 \%$ molekul ini mengalami deiodinasi perhari. Karena mengandung iodium, amiodaron berpotensi menyebabkan disfungsi tiroid. Dosis pemeliharaan sebesar 200-600 mg per hari melepaskan 6-21 mg iodium bebas per harinya. Beban iodium ini jauh melebihi rekomendasi World Health Organisation (WHO) terhadap asupan optimal iodium per hari yaitu $0,15-0,3 \mathrm{mg}$ per hari. Pada pasien yang diberi amiodaron, kadar iodium anorganik di urin dan plasma ditemukan meningkat 50-100 kali melebihi kebutuhan iodium harian. ${ }^{5-8}$

\section{Farmakokinetik}

Amiodaron bersifat sangat lipofilik dan didistribusikan ke berbagai jaringan seperti jaringan adiposa, miokardium, hati dan paru-paru. Sekitar 35-65\% obat ini diabsorbsi setelah pemberian oral. Waktu bekerjanya setelah pemberian oral berlangsung lambat dan kadar yang stabil dalam darah (amiodaronisasi) mungkin belum tercapai selama beberapa bulan, kecuali bila dosis besar diberikan pada awal pemakaian. Bahkan dengan pemberian intravena, efek penuh elektrofisiologisnya lambat tercapai. Saat pemberian awal secara intravena amiodaron intravena seakan cepat 'menghilang' dari plasma karena redistribusi ke jaringan bukan karena eliminasi keluar dari tubuh. Karena redistribusi di jaringan ini dibutuhkan loading dose sebelum konsentrasinya stabil (steady state) di jaringan. Amiodaron tidak diekskresikan melalui ginjal namun melalui kelenjar lakrimal, kulit, dan traktus biliaris. Sebagian besar (66-75\%) dieliminasi melalui empedu dan feses. ${ }^{3,5-7}$

Amiodaron mengalami metabolisme di 
hati menjadi metabolit aktif, yaitu desetil amiodaron (DEA). Terdapat variasi individual antara konsentrasi amiodaron dan desetil amiodaron yang dihubungkan dengan supresi antiaritmik. Kadar terapeutik dalam plasma sampai saat ini belum didefinisikan dengan pasti, mungkin berkisar antara 1,0$2,5 \mathrm{mg} / \mathrm{ml}$ dan hampir semuanya $(95 \%)$ terikat dengan protein. Kadar yang lebih tinggi (> 2,5 $\mathrm{mg} / \mathrm{ml}$ ) dihubungkan dengan meningkatnya toksisitas. ${ }^{5-7}$

Pada analisis jaringan post mortem, ditemukan konsentrasi amiodaron yang bervariasi di berbagai jaringan. Konsentrasi amiodaron intratiroid dan DEA ditemukan $14 \mathrm{mg} / \mathrm{kg}$ dan $64 \mathrm{mg} / \mathrm{kg}$, sedangkan di jaringan lain yaitu adiposa sebesar $316 \mathrm{mg} / \mathrm{kg}$ dan $76 \mathrm{mg} / \mathrm{kg}$, hepar $391 \mathrm{mg} / \mathrm{kg}$ dan 2354 $\mathrm{mg} / \mathrm{kg}$. Dalam satu studi, pada 8 pasien setelah pemberian amiodaron jangka panjang eliminasi terminal waktu paruh rata-rata 52,6 \pm 23,7 hari untuk amiodaron dan 61,2 \pm 31,2 untuk DEA. Di studi lain ditemukan eliminasi waktu paruh adalah $40 \pm 10$ hari untuk amiodaron dan $57 \pm 27$ hari untuk DEA. Hasil di atas menjelaskan mengapa setelah penghentian amiodaron obat dan metabolitnya tetap ada untuk jangka waktu yang lama. ${ }^{3,7}$

\section{Indikasi}

Efek antiaritmia amiodaron merupakan hasil interaksinya dengan sistem konduksi jantung. Penggolongan obat antiaritmia dibagi menjadi empat kelas berdasarkan mekanisme ionik dan reseptor obat pada proses potensial aksi di sistem konduksi jantung. Amiodaron termasuk golongan III, yaitu obat aritimia yang terutama bekerja di saluran $\mathrm{K}^{+}$sehingga memperpanjang durasi potensial aksi dan interval QT. Mekanisme kerja amiodaron juga meliputi aktivitas obat aritmia kelas I, II, dan IV sehingga disebut sebagai obat aritmia dengan spektrum luas dan cukup efektif digunakan pada berbagai macam aritmia. ${ }^{1}$ Di antaranya adalah paroksismal supraventrikuler aritmia sebagai agen pilihan kedua setelah adenosin dan calcium channel blocker nondihidropiridin, sebagai obat kardioversi untuk fibrilasi atrium, dan sebagai pilihan utama untuk takiaritmia ventrikuler. ${ }^{1}$

Amiodaron direkomendasikan untuk beberapa keadaan, antara lain: terapi pada VT tanpa nadi atau VF yang refrakter terhadap defibrilasi; terapi VT polimorfik atau takikardia dengan QRS kompleks yang lebar yang tidak diketahui sebabnya; kontrol VT dengan hemodinamik stabil apabila kardioversi tidak berhasil, sangat berguna terutama bila fungsi ventrikel kiri menurun; sebagai obat tambahan pada kardioversi supraventrikular takikardia atau paroksismal supraventrikular takikardi; dapat digunakan untuk terminasi takikardia atrial multifokal atau ektopik dengan fungsi ventrikel kiri yang masih baik; dapat digunakan untuk kontrol denyut jantung pada atrial fibrilasi atau atrial flutter bila terapi lain tidak efektif. $^{8}$

\section{Dosis}

Pada keadaan di mana efek antiaritmia amiodaron dibutuhkan cepat, dosis awal oral (loading dose) dapat sebesar 800-1600 $\mathrm{mg} /$ hari dalam 3-4 dosis sedangkan secara intravena dalam satu hari dapat diberikan sampai $1000 \mathrm{mg}$. Pada keadaan yang lebih ringan amiodaron oral diberikan dengan dosis awal $600 \mathrm{mg}$ per hari. Loading dose ini dapat diberikan selama 7-14 hari sampai aritmia dapat dikontrol lalu diturunkan lagi menjadi 400-800 mg/hari untuk satu sampai tiga minggu berikutnya. Besar dosis pemeliharaan yang diberikan untuk jangka panjang tergantung dari aritmianya; pada atrial flutter atau fibrilasi atrial dosisnya dapat lebih kecil yaitu $100 \mathrm{mg} / \mathrm{hari}$ dibandingkan dengan 200-400 mg/hari untuk kontrol aritmia ventrikuler. ${ }^{1}$

\section{Efek samping}

Penggunaan amiodaron telah dihubungkan dengan beberapa efek samping kardiak dan non kardiak. Amiodaron dapat menyebabkan blok pada nodus SA atau AV sehingga dapat menyebabkan bradikardia berat dan membutuhkan alat pacu jantung permanen. Bradikardia ini jarang terjadi dan biasanya terjadi pada pasien dengan dis- 
fungsi nodus SA atau blok AV. Dari satu meta-analisa, amiodaron hanya dihentikan pada $1,6 \%$ pasien karena bradikardia. Pemberian amiodaron juga dapat menyebabkan Torsade de Pointes, namun dari beberapa studi amiodaron insidens komplikasi ini cukup rendah $(<0,5 \%)$. Insidens komplikasi ini dihubungkan dengan keadaan pemanjangan interval QT, hipokalemia atau toksisitas digitalis. ${ }^{1,2}$

Pada organ non kardiak, amiodaron dapat menyebabkan fotosensitivitas di kulit, deposit mikro di kornea, toksisitas paru, hepatotoksisitas, neuropati perifer, tirotoksikosis dan hipotiroidisme. Pada dosis yang besar (> 400mg/hari), pneumonitis dan fibrosis paru dapat terjadi pada $10-17 \%$ pasien. Efek pada paru ini mungkin tergantung dosis dan jarang sekali terjadi pada dosis < 200 mg/hari. Uji klinis Amiodarone Trials Meta-Analysis Investigators melaporkan sebanyak $1 \%$ pasien yang mendapat komplikasi ini dengan penggunaan amiodaron selama satu tahun. Studi ini juga melaporkan persentase efek samping lain yaitu $0,6 \%$ untuk toksisitas hati, $0,3 \%$ untuk neuropati perifer, dan $0,9 \%$ untuk tirotoksikosis. Hipotiroidisme ternyata lebih sering ter-

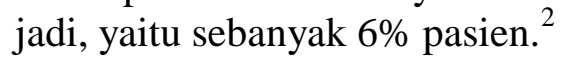

\section{AMIODARON DAN FUNGSI TIROID}

Amiodaron dan metabolitnya DEA mempengaruhi hormon tiroid pada kelenjar tiroid, jaringan perifer, dan mungkin pada pituitari. Aksi amiodaron ini menyebabkan peningkatan T4, rT3 dan TSH, namun menurunkan kadar T3. Baik hipotiroidisme maupun tirotoksikosis dapat terjadi pada pasien yang diberi amiodaron.

\section{Efek amiodaron terhadap sintesis hor- mon tiroid}

Iodium dalam jumlah besar yang dilepas selama metabolisme amiodaron menyebabkan inhibisi adaptif ambilan iodium oleh tiroid dan biosintesis hormon tiroid (efek Wolff-Chaikoff). Walaupun efek ini jelas terjadi dalam dua minggu pertama terapi, paparan lebih lanjut terhadap iodium akan menormalkan kembali sintesis hormon tiroid. Kemampuan tiroid untuk lepas dari efek Wolff Chaikoff melindungi seseorang dari kemungkinan hipotiroid yang disebabkan oleh efek ini. ${ }^{5-7,9}$

\section{Efek amiodaron terhadap metabolisme hormon tiroid}

Di dalam jaringan, amiodaron mempunyai kemampuan spesifik menghambat deiodinasi T4 oleh enzim 5' monodeiodinasi. Perubahan konsentrasi serum dari T4, T3, rT3 dan TSH yang disebabkan amiodaron ini bersifat dose-dependent. ${ }^{5,6}$

Amiodaron menghambat aktivitas 5 'monodeiodinase tipe I secara kuat dan menyebabkan penghambatan konversi fraksional T4 menjadi T3. Menurunnya proses ini dapat diamati pada hampir semua jaringan, namun paling nyata di kelenjar tiroid dan hati. Aksi inhibisi ini menetap selama beberapa bulan setelah terapi amiodaron, sehingga selama periode ini konsentrasi T3 plasma dan jaringan menurun, sedangkan konsentrasi T4 meningkat. Perubahan konsentrasi hormon tiroid ini dapat dideteksi sekitar dua minggu setelah pemberian amiodaron. ${ }^{4,5,7}$

Amiodaron secara tidak langsung mempengaruhi metabolisme tiroid dengan cara menghambat masuknya hormon tiroid ke dalam sel. Hasil dari studi kinetik menunjukkan transfer T4 dari plasma ke jaringan seperti di hati menurun. Hal ini mengurangi simpanan substrat T4 intrasel sehingga menurunkan produksi T3. Penurunan selektif transport T4 di hati juga ditunjukkan pada hepatosit tikus dan gangguan ambilan T3 diobservasi terjadi di sel-sel pituitari. ${ }^{7,9,10}$

Perubahan kadar hormon TSH bukan hanya disebabkan oleh perubahan kadar hormon tiroid. Ternyata amiodaron dapat mempengaruhi sintesis dan sekresi TSH langsung di tingkat pituitari. Amiodaron atau DEA menghambat 5' monodeiodinase tipe II di pituitari. Perubahan TSH ini bahkan dapat dideteksi pada hari pertama pemberian amiodaron dengan dosis loading intravena. Selama pemakaian jangka panjang dengan amiodaron, fluktuasi kadar TSH dapat 
terjadi pada pasien dengan klinis eutiroid. ${ }^{7}$

\section{Efek sitotoksik amiodaron terhadap ke- lenjar tiroid}

Chiovato et al. melaporkan efek sitotoksik amiodaron terhadap sel tiroid, yaitu terjadinya lisis folikel tiroid manusia, yang bertambah pada peningkatan konsentrasi amiodaron (Gambar 2). Studi dengan hewan coba memperlihatkan amiodaron juga bersifat sitotoksik terhadap sel-sel jaringan lain. Data ini menunjukkan bahwa amiodaron mempunyai efek langsung sitotoksik terhadap sel-sel tiroid. DEA yang merupakan metabolit utama amiodaron ternyata bersifat lebih sitotoksik terhadap sel-sel tiroid. ${ }^{11}$

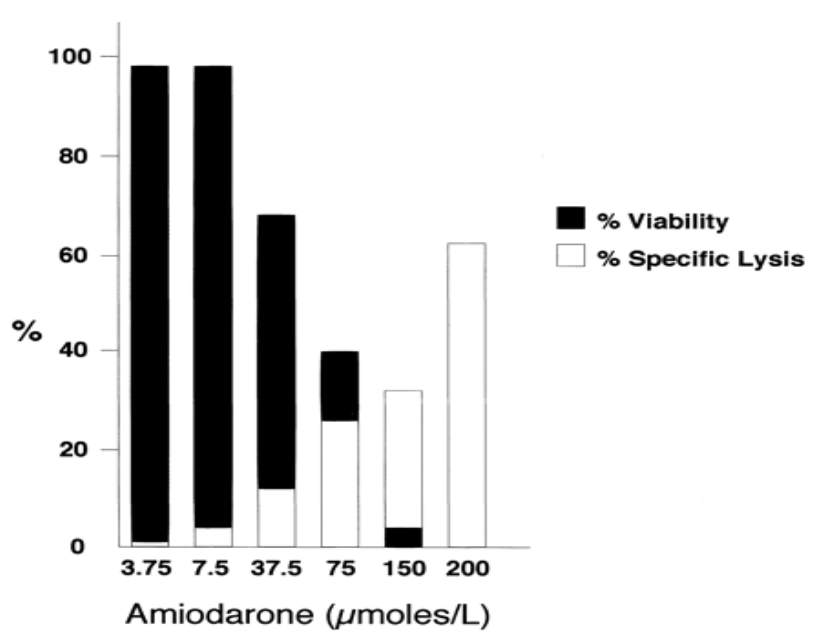

Gambar 2. Efek sitotoksik amiodaron terhadap folikel tiroid manusia. Batang hitam menunjukkan sel yang viable; batang putih menunjukkan sel yang lisis. Sumber: Chiovato et al, 1994. ${ }^{11}$

Pada hewan coba tikus, terdapat perubahan histopatologik sel-sel tiroid yang mengindikasikan efek sitotoksik amiodaron. Perubahan ini termasuk distorsi yang nyata pada arsitektur tiroid, apoptosis, nekrosis, badan inklusi, lipofusinogenesis, infiltrasi makrofag, dan pembengkakan retikulum endoplasma yang nyata. Kelainan yang serupa juga dideteksi pada organ-organ lain, seperti hati, paru-paru, jantung, kulit, kornea, saraf tepi dan leukosit; nampaknya dihubungkan dengan pemberian obat jangka panjang. ${ }^{12}$
Pada hewan coba anjing, perubahan subseluler tiroid tidak terdeteksi pada pemberian amiodaron intravena dosis tinggi. Kelainan nyata baru terjadi setelah pemberian injeksi berulang selama satu minggu. ${ }^{7}$

\section{Efek amiodaron terhadap autoimunitas kelenjar tiroid}

Efek amiodaron terhadap autoimunitas kelenjar tiroid masih dalam perdebatan. Studi prospektif pada 37 pasien secara random diberikan plasebo dan amiodaron. Antibodi antitiroid peroksidase dalam serum ditemukan de novo pada 6 dari $13(55 \%)$ pasien yang menerima amiodaron, namun tidak pada satupun pasien yang menerima plasebo. Autoantibodi yang ditemukan di awal pemberian amiodaron ini tidak terdeteksi setelah enam bulan penghentian obat. Fenomena ini mungkin diakibatkan oleh efek toksik amiodaron yang menyebabkan pelepasan autoantigen tiroid dan memicu reaksi autoimun. Beberapa studi lain menemukan hasil yang berbeda. Safran et al tidak menemukan peningkatan insiden autoantibodi antitiroid pada 47 pasien yang menerima amiodaron. Foresti et al menemukan autoantibodi tiroid titer rendah pada 2 dari 23 pasien yang mendapat amiodaron. ${ }^{7}$

\section{Profil hormon tiroid pada pemberian amiodaron}

Perubahan metabolisme tiroid yang disebabkan amiodaron seperti yang telah dideskripsikan sebelumnya menjelaskan bahwa tes fungsi tiroid pada pasien eutiroid yang menerima amiodaron mempunyai kisaran berbeda dengan pasien eutiroid yang tidak diberikan amiodaron. Efek akut pemberian amiodaron terhadap fungsi tiroid pada 24 pasien dengan artimia diteliti selama 10 hari pertama terapi. Kadar TSH diobservasi sejak awal terapi dan didapatkan peningkatan lebih awal secara bermakna selama studi, dan mencapai nilai 2,7 kali dari nilai basal saat hari kesepuluh. Kadar T3 total menurun progresif mulai dari hari kedua studi sedangkan rT3 meningkat secara progresif dan bermakna, paralel dengan kenaikan TSH. 
Tabel 1. Profil hormon tiroid pada pasien dalam keadaan eutiroid. ${ }^{5}$

\begin{tabular}{lcc}
\hline & & Durasi Pengobatan \\
Parameter (serum) & $<3$ bulan & $>3$ bulan \\
\hline T4 atau T4 bebas & $\uparrow$ & $\uparrow$ (naik sampai $40 \%>$ dari nilai dasar) \\
T3 atau T3 bebas & $\downarrow$ & $\downarrow$ atau normal rendah \\
Reverse T3 (rT3) & $\uparrow$ & $\uparrow$ \\
TSH & $\uparrow$ (sampai $20 \mathrm{mU} / \mathrm{l})$ & Normal \\
\hline
\end{tabular}

Tabel 2. Perbedaan AIT tipe I dan II. ${ }^{7}$

\begin{tabular}{|c|c|c|}
\hline & AIT tipe I & AIT tipe II \\
\hline $\begin{array}{l}\text { Abnormalitas tiroid yang } \\
\text { sudah ada sebelumnya }\end{array}$ & + & - \\
\hline Pemeriksaan leher & $\begin{array}{l}\text { Struma multinoduler atau } \\
\text { difusa }\end{array}$ & $\begin{array}{l}\text { Normal atau struma } \\
\text { yang kecil }\end{array}$ \\
\hline Durasi tirotoksikosis & Lama & Biasanya sementara \\
\hline Ambilan radioaktif & Normal sampai tinggi & Rendah atau absen \\
\hline Kadar IL-6 serum & Normal atau sedikit tinggi & Sangat tinggi \\
\hline $\begin{array}{l}\text { Aliran darah parenkim pada } \\
\text { Color flow Doppler }\end{array}$ & + & - \\
\hline
\end{tabular}

Nilai rT3 mencapai dua kali dari nilai basal pada hari ke-10. Hal ini diikuti oleh peningkatan kadar $\mathrm{T} 4$ total dan $\mathrm{T} 4$ bebas yang bermakna, dimulai dari hari keempat terapi. Kenaikan ini mungkin ka-rena stimulasi langsung oleh TSH dan penurunan bersihan $\mathrm{T} 4 .^{5-7}$

Setelah 1-4 bulan terapi amiodaron, kadar serum T4 meningkat, rata-rata 40\% di atas kadar sebelum terapi. Kadar TSH sering kali kembali ke nilai normal setelah pemberian amiodaron secara kronik ( $>3$ bulan). Normalisasi kadar TSH serum terjadi saat konsentrasi T4 meningkat dan mencukupi untuk mengatasi blok produksi T3. Namun konsentrasi TSH dapat menurun bila terapi amiodaron diberikan dalam jangka waktu yang lebih lama. Efek amiodaron terhadap profil hormon tiroid pada pasien eutiroid dirangkum pada Tabel 1.

\section{GANGGUAN FUNGSI TIROID YANG DIINDUKSI AMIODARON}

Pemahaman yang cermat mengenai mekanisme terjadinya hipotiroidisme dan tirotoksikosis yang diinduksi amiodaron, gam- baran klinis dan tatalaksana sangat dibutuhkan dalam penanganan yang efektif.

\section{Hipotiroidisme yang diinduksi oleh amio- daron (amiodarone-induced hypothyroid- ism, AIH)}

AIH disebabkan oleh ketidakmampuan tiroid melepaskan diri dari efek WolffChaikoff. Biosintesis hormon tiroid terganggu karena hambatan persisten pada organifikasi iodium intratiroid, yang dibuktikan oleh hasil positif dari tes pelepasan perklorat (perchlorate discharge test) pada pasien AIH. Hal ini mungkin terjadi pada pasien yang memang fungsi tiroidnya abnormal (seperti tiroiditis autoimun) sebelum terapi amiodaron. Autoantibodi tiroid yang positif ditemukan pada $40 \%$ pasien yang mengalami hipotiroid setelah pemberian amiodaron. Hal ini menunjukkan bahwa kelebihan beban iodium dapat menyebabkan penyakit tiroid subklinis bermanifestasi klinis sebagai kegagalan fungsi tiroid. ${ }^{5-7}$

Insidens AIH bervariasi namun terjadi lebih sering di area dengan asupan iodum yang cukup. Risiko meningkat pada wanita dengan rasio wanita : laki-laki $1,5: 1$, dan 
risiko relatifnya sebesar 7,9 . Insiden juga meningkat pada populasi usia tua. AIH dapat timbul pada pasien dengan tiroid yang normal atau yang sudah ada kelainan. Risiko relatif timbulnya AIH ditemukan 13 kali lebih tinggi pada wanita dengan antibodi mikrosomal tiroid atau antibodi tiroglobulin yang positif. Risiko relatif timbulnya AIH sebesar 7,3 dengan adanya antibodi antitiroid. Studi lain menunjukkan terjadinya AIH dengan pemakaian amiodaron jangka panjang pada 5 dari 7 pasien dengan antibodi antitiroid yang positif. ${ }^{4-7,13}$

Risiko timbulnya hipotiroidisme ini tidak tergantung pada dosis amidaron kumulatif atau harian. AIH dapat berlangsung sementara atau menetap. Kelainan yang menetap hampir selalu dihubungkan dengan kelainan tiroid yang sudah ada sebelumnya. Lain halnya dengan tirotoksikosis yang dapat muncul kapan saja selama terapi atau setelah terapi dihentikan, hipotiroidisme biasanya terjadi pada awal terapi dan jarang terjadi setelah 18 bulan pertama terapi. ${ }^{5-7}$

Gambaran klinis hipotiroidisme biasanya tidak jelas. Pasien dengan AIH sering mengeluhkan rasa lelah, letargi, tidak tahan dingin, dan kulit yang kering. Diagnosis AIH dikonfirmasi dengan peningkatan konsentrasi TSH (biasanya > 20mU/l) disertai kadar T4 bebas yang rendah. Konsentrasi T3 serum merupakan indikator yang tidak dapat diandalkan untuk diagnosis karena pada pasien eutiroid kadarnya bisa rendah, sedangkan pada pasien hipotiroidisme kadar T3 bisa dalam kisaran normal. Walaupun terdapat beban iodium yang besar pada terapi amiodaron, umumnya pasien AIH mempunyai hasil ambilan iodium radioaktif yang meningkat. $^{5-7}$

Tirotoksikosis yang diinduksi oleh amiodaron (amiodarone-induced thyrotoxycosis/AIT)

AIT ditemukan pada $2-12 \%$ pasien yang diberikan amiodaron. Beberapa studi menununjukkan insiden yang bervariasi, tergantung asupan iodium dalam populasi. Pada beberapa studi, AIT lebih sering terjadi pada populasi dengan diet rendah iodium (contoh: Eropa Tengah) dibandingkan populasi dengan asupan iodium cukup (contoh: Amerika Utara dan Inggris) (Gambar 3). Hipotiroidisme lebih banyak terjadi pada area dengan asupan iodium cukup seperti di Worcester, Amerika Serikat, sedangkan hipertiroidisme lebih banyak terjadi di area dengan asupan iodium yang rendah seperti di Tuscany, Italia Utara. Namun, salah satu studi di Belanda yang melibatkan subjek eutiroid dalam area di mana asupan iodium dinilai cukup, insiden AIT dua kali lebih banyak dari AIH. ${ }^{5,7,14}$

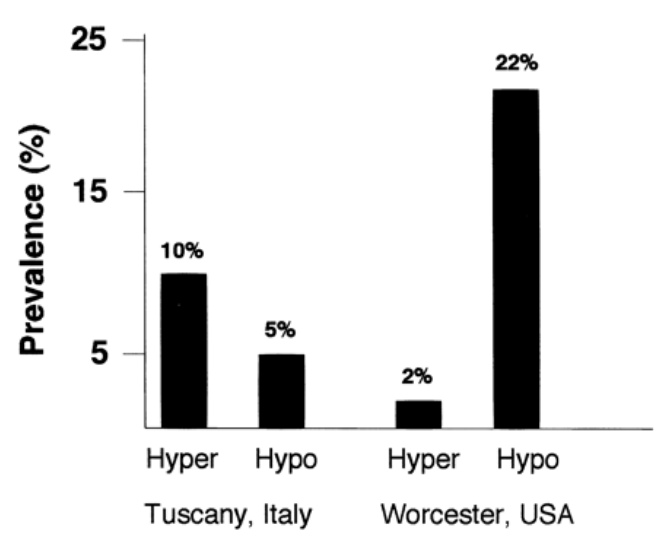

Gambar 3. Prevalensi hipertiroidisme dan hipotiroidisme yang diinduksi amiodaron pada area dengan defisiensi iodium di Tuscany Utara, Italia dan di area dengan asupan iodium yang cukup di Worcester, Massachussets, Amerika Serikat. Gambar dikutip dari E. Martino et al.: Ann Intern Med 101:28-34, 1984 (62)

AIT dapat terjadi mendadak, saat awal atau bahkan setelah beberapa tahun terapi amiodaron. Trip et al melaporkan durasi rata-rata terjadinya AIT adalah 3 tahun setelah dimulainya terapi amiodaron. Mariotti et al melaporkan AIT terjadi 21-47 bulan setelah terapi amiodaron. Hal ini mungkin terjadi karena amiodaron dan metabolitnya disimpan di dalam jaringan sehingga efeknya menetap untuk jangka waktu yang lama setelah amiodaron dihentikan. Seperti halnya hipotiroidisme, tidak terdapat hubungan antara dosis kumulatif amiodaron dengan insiden tirotoksikosis. ${ }^{7}$

Pada pasien dengan kelainan tiroid, 
tirotoksikosis mungkin merupakan akibat dari kelebihan sintesis hormon tiroid yang diinduksi oleh iodium (AIT tipe I). Patogenesisnya terkait dengan efek beban iodium yang berlebihan pada kelenjar tiroid yang abnormal seperti nodul otonom atau penyakit Grave yang laten. Karena perubahan mekanisme autoregulasi intrinsik yang mengatur metabolisme iodium di tiroid, hipertiroid terjadi pada kelebihan iodium pada mereka yang rentan (susceptible). Pada pasien dengan abnormalitas tiroid (struma difusa atau noduler, penyakit Grave yang laten) terjadi peningkatan ambilan iodium radioaktif (radioactive iodium uptake/ RAU) selama 24 jam lebih tinggi. Pada pemeriksaan ultrasonografi (USG) dengan color flow Doppler, didapatkan gambaran tiroid yang hiperfungsi dan hipervaskuler. ${ }^{5-7,14}$

Pada pasien dengan fungsi kelenjar tiroid normal, tirotoksikosis disebabkan oleh kerusakan kelenjar sehingga terjadi pelepasan hormon tiroid yang sudah dibentuk ke dalam sirkulasi (AIT tipe II). Studi histopatologik memperlihatkan terjadinya kerusakan folikel, vakuolisasi sitoplasma, dan fibrosis jaringan tiroid. Temuan interleukin-6 (IL-6) yang meningkat bermakna pada pasien AIT tipe II mendukung penjelasan mengenai proses destruktif akibat inflamasi. Pada pasien AIT tipe I kadar IL-6 normal atau sedikit meningkat. ${ }^{7,15}$

Tirotoksikosis pada pasien AIT tipe II biasanya self limiting, dan dapat dijelaskan dengan efek sitotoksik amiodaron. Saat konsentrasi amiodaron melebihi ambang tertentu, kerusakan sel menyebabkan tirotoksikosis karena kebocoran hormon ke aliran darah. Konsentrasi amiodaron intratiroid juga menurun dan terjadi perbaikan menuju keadaan eutiroid. Kadang-kadang hipotiroidisme terjadi akibat destruksi folikel yang berlebihan dan pasien membutuhkan substitusi hormon tiroksin. ${ }^{5,7}$

Terjadinya tirotoksikosis dicurigai bila pasien yang diberi amiodaron mengalami penurunan berat badan tanpa sebab yang jelas, berkeringat banyak, tremor, sinus takikardia atau perburukan aritmia. Namun beberapa pasien mungkin saja tidak mengalami gejala klasik tirotoksikosis. Bila timbul aritmia supraventrikular seperti takikardia atrial atau atrial fibrilasi, maka AIT perlu dicurigai sebagai penyebabnya. Timbulnya tirotoksikosis seringkali tidak dapat diprediksi, dapat terjadi mendadak dan eksplosif tanpa temuan biokimia subklinis sebelumnya, sehingga sangat penting untuk memberikan edukasi mengenai gejala tirotoksikosis dan untuk mendapatkan pengobatan secepatnya. Terjadi peningkatan kadar T4 serum, dengan TSH serum seringkali tertekan bahkan sampai tidak terdeteksi. Kadar serum T3 dapat saja normal atau meningkat.

Walaupun pembedaan antara kedua bentuk AIT sering tidak mudah, namun hal ini penting untuk pemberian terapi yang tepat. Studi RAU pada tiroid dapat sangat membantu. Ambilan 24 jam biasanya normal sampai tinggi pada pasien AIT tipe I, namun rendah pada AIT tipe II. Pengukuran kadar IL-6 juga merupakan indikator, yang di masa depan mungkin bisa digunakan untuk membedakan kedua tipe AIT. Color flow Doppler sonography dapat digunakan untuk membedakan AIT tipe I dan tipe II dimana aliran darah parenkim meningkat pada AIT tipe I dan nihil pada AIT tipe II. ${ }^{5-}$ 7,16 Tabel 2 merangkum perbedaan AIT tipe I dan II.

\section{TATALAKSANA KELAINAN TIROID YANG DIINDUKSI AMIODARON (AIH DAN AIT)}

\section{Tatalaksana AIH}

AIH dapat ditangani dengan cara menghentikan terapi amiodaron atau pemberian subsitusi hormon tiroid. Penghentian amiodaron mungkin tidak dapat dilakukan karena adanya indikasi, terutama dalam penanganan takiaritmia ventrikular. Alternatif yang lebih aman adalah memberikan substitusi hormon terapi, dimulai dengan 25-50 $\mu \mathrm{g}$ laevothyroxine per hari, dan ditingkatkan dengan interval 4-6 minggu sampai gejala berkurang dan target $\mathrm{T} 4$ serum tercapai. Tujuan terapi adalah meningkatkan T4 sampai batas atas dari kisaran normal, sesuai dengan gambaran pasien eutiroid yang men- 
dapat terapi amiodaron. Penting diperhatikan bahwa pada pasien dengan amiodaron kadar serum TSH nya dapat meningkat ringan walaupun sudah diberi substitusi hormon tiroid yang cukup.

Pada beberapa studi kecil, terapi dengan perklorat menunjukkan bahwa fungsi tiroid kembali normal dengan cepat pada pasien AIH. Obat ini menghambat masuknya iodium ke kelenjar tiroid, sehingga mengurangi efek inhibisi sintesis yang diakibatkan kelebihan iodium. Namun karena toksisitas perklorat dapat terjadi pada pemakaian jangka panjang atau dengan dosis tinggi (> $1 \mathrm{~g} /$ hari), penggunaanya tidak direkomendasikan karena adanya alternatif pengobatan AIH yang lebih aman dan efektif yaitu dengan substitusi hormon tiroid. ${ }^{5-7}$

Tidak adanya gejala hipotiroidisme atau antibodi tiroid pada pasien dengan kadar serum TSH yang meningkat moderat $(<20$ $\mathrm{mU} / \mathrm{l}$ ) namun $\mathrm{T} 4$ bebas meningkat atau normal tinggi, merefleksikan perubahan parameter fungsi tiroid yang diinduksi oleh amiodaron atau hipotiroid subklinis. Pada kondisi ini pasien belum memerlukan terapi substitusi tiroid namun perlu dipantau fungsi tiroidnya. $^{5}$

\section{Tatalaksana AIT}

Tidak seperti hipotiroidisme yang relatif lebih mudah diobati dengan terapi subtitusi, manajemen tirotoksikosis lebih sulit dan bisa bervariasi individual. Pasien dengan tirotoksikosis ringan dan kelenjar tiroid normal atau terdapat struma kecil, perbaikan dapat terjadi cepat setelah penghentian amiodaron. Tindakan ini dimungkinkan bila aritmia jantung tidak mengancam hidup dan dapat dikendalikan dengan obat antiaritmia lainnya. Terapi definitif juga diberikan seperti tionamid, dosis tinggi kortikosteroid, perklorat, litium, plasmafaresis, dan operasi. ${ }^{5-7}$

Pada pasien dengan kelenjar tiroid abnormal dan AIT tipe I yang berat, tionamid dapat menghambat sintesis hormon tiroid. Pada keadaan ini diperlukan dosis tinggi (sebagai contoh: carbimazole atau metimazole $40-60 \mathrm{mg} / \mathrm{hari}$, atau propiltiourasil 600 -
$800 \mathrm{mg} / \mathrm{hari})$. Walaupun dosis dapat diturunkan pada kebanyakan kasus setelah 6-12 minggu, terapi antitiroid jangka panjang diberikan pada pasien yang tetap memakai amiodaron. Beberapa peneliti lebih memilih melanjutkan terapi antitiroid untuk menghambat sintesis hormon daripada menghentikan terapi amiodaron. ${ }^{5-7}$

Bila tirotoksis berat dan pemberian tionamid tidak adekuat dalam mengatasi tirotoksikosis, potasium perklorat dengan dosis $250 \mathrm{mg}$ setiap 6 jam dapat diberikan untuk kontrol yang efektif. Perklorat secara kompetitif menghambat iodium yang masuk kelenjar tiroid melalui simporter $\mathrm{Na}+/ \mathrm{I}-$, namun tidak berefek melalui proses iodinasi. Perklorat dikonsentrasikan oleh jaringan tiroid dengan cara serupa seperti halnya iodium, namun tidak mengalami metabolisme di kelenjar maupun jaringan. Kombinasi potasium perklorat dan metimazole nampaknya efektif pada pasien dengan tirotoksikosis berat, kemungkinan besar karena perklorat menghambat transpor iodium ke dalam tiroid, sementara metimazole menghambat sintesis hormon dalam jaringan tiroid. Perklorat harus diturunkan dosisnya (tapering off) dan dihentikan setelah periode 4-6 minggu, sedangkan metimazol dilanjutkan sampai keadaan eutiroidisme tercapai. Penggunaan jangka panjang perklorat tidak dianjurkan karena dapat menimbulkan efek samping yang berat yaitu anemia aplastik, agranulositosis, dan gangguan fungsi ginjal. Insidens toksisitas perklorat meningkat bila dosis lebih dari $1 \mathrm{~g} /$ hari. $^{5,17}$

Dalam salah satu studi kecil, penambahan litium karbonat (900-1350 mg/hari selama 4-6 minggu) dilaporkan dapat mempercepat tercapainya keadaan eutiroid pada pasien dengan tirotoksikosis berat. Belum diteliti pemakaian jangka panjang litium bila amiodaron terus diberikan pada pasien. ${ }^{7,18}$

Pada pasien dengan kelenjar tiroid normal (AIT tipe II), tirotoksikosis biasanya hanya sementara dan membaik apabila amiodaron dihentikan. Kadang-kadang remisi spontan dapat terjadi walaupun pemberian amiodaron diteruskan. Tionamid tanpa atau dengan potasium perklorat bukanlah terapi yang tepat untuk AIT tipe II yang di- 
sebabkan tiroiditis destruktif. Steroid adalah terapi pilihan pada keadaan ini. Selain mempunyai efek anti-iflamasi, steroid juga dapat menghambat aktivitas enzim 5'deiodinase. Steroid telah digunakan pada pasien AIT dengan dosis yang berbeda (15-80 mg prednison atau 3-6 mg dexametason per hari) dan dengan durasi berkisar 7-12 minggu. Rekurensi tirotoksikosis dapat terjadi bila terapi steroid dihentikan, sehingga pada keadaan ini pemberian steroid harus dimulai lagi. Untuk pasien AIT bentuk campuran (AIT tipe I dan II) kombinasi metimazol, potasium perklorat, dan steroid mungkin efektif. $^{5-7,19,20}$

Pada beberapa keadaan dimana tidak ada respon dengan obat-obatan dan terapi amiodaron harus diteruskan, tiroidektomi total atau subtotal perlu dipertimbangkan dalam mengendalikan tirotoksikosis. Setelah tindakan ini, terapi amiodaron dapat diberikan. ${ }^{5-7}$

Iodium radioaktif biasanya tidak efektif dalam manajemen pasien AIT karena konsentrasi iodium yang tinggi mengakibatkan ambilan radioisotop tidak adekuat. Namun pada pasien dengan struma difusa atau noduler mungkin saja mempunyai ambilan iodium radioaktif yang normal atau tinggi; pada mereka ini terapi ablasi mungkin berespons. Pada pasien dengan riwayat AIT dan memerlukan terapi amiodaron lagi (setelah penghentian terapi ini), ablasi dengan radioiodium perlu dipertimbangkan untuk menghindari AIT.

Plasmaferesis telah dicoba dengan hasil yang baik pada pasien dengan tirotoksikosis berat dan tidak berespon terhadap medikamentasosa. Tujuan tindakan ini untuk menghilangkan kelebihan hormon tiroid. Terapi ini kadang-kadang berhasil namun efeknya hanya sementara dan diikuti oleh eksaserbasi AIT. ${ }^{5,7}$

\section{Pemantauan fungsi tiroid pada pasien yang diberi amiodaron}

Sangat penting untuk mengevaluasi pasien sebelum dan sesudah terapi dengan amiodaron. Evaluasi meliputi pemeriksaan fisik kelenjar tiroid, tes fungsi tiroid dan bila perlu USG tiroid. Pemeriksaan ini sebaiknya dilakukan di awal sebagai data dasar dan untuk mendeteksi adanya kelainan tiroid. Tes fungsi tiroid dievaluasi setelah tiga bulan terapi amiodaron. Pada pasien eutiroid, tes fungsi tiroid saat evaluasi ini merupakan nilai rujukan sebagai perbandingan selanjutnya. Dalam follow-up selanjutnya hanya kadar serum TSH dievaluasi, sedangkan indeks tiroid lainnya diperiksa bila hasil TSH abnormal atau bila ada kecurigaan klinis terjadi disfungsi tiroid. ${ }^{5-7} \mathrm{Gam}-$ bar 6 memperlihatkan rangkuman algoritme pemantauan fungsi tiroid pada pasien yang menerima amiodaron. ${ }^{5}$

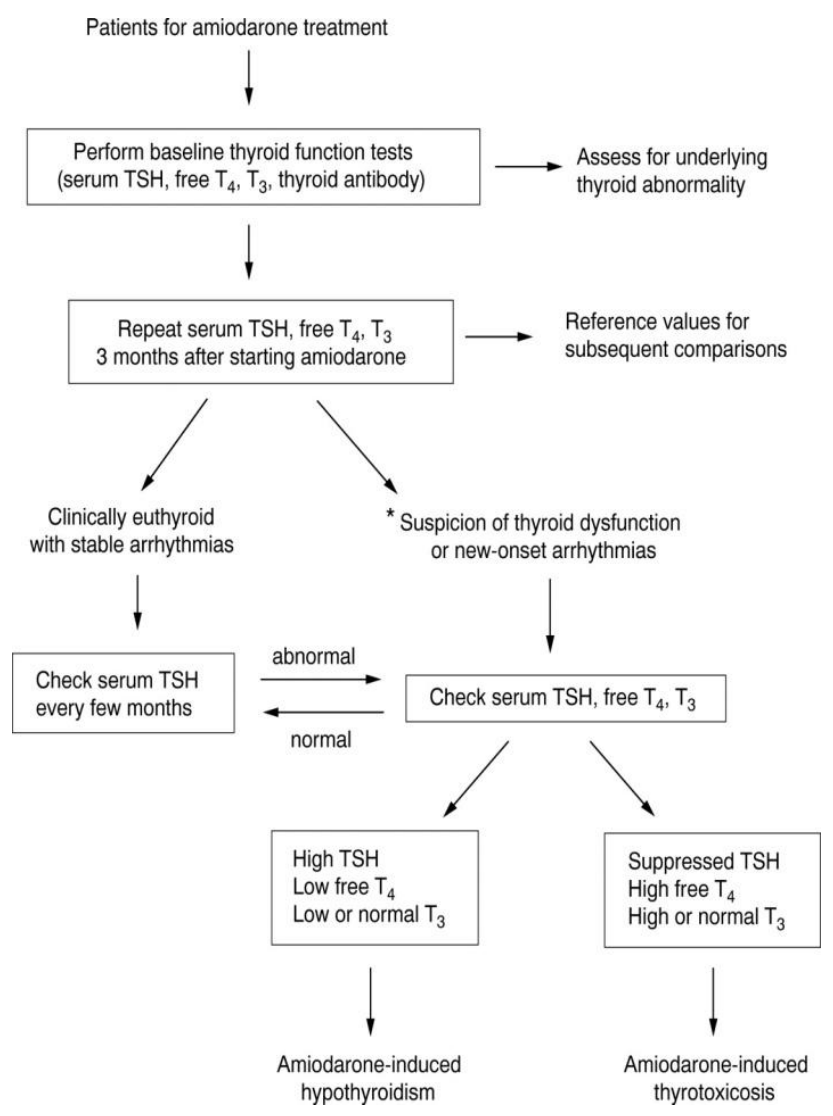

Gambar 6. Algoritme monitor fungsi tiroid pada pasien yang diberi amiodaron. ${ }^{5}$

\section{SIMPULAN}

Amiodaron bekerja cukup efektif dalam menangani beberapa keadaaan aritmia mulai dari supraventrikuler takikardia sampai taki- 
kardia ventrikuler yang mengancam kehidupan. Namun perlu diwaspadai terjadinya efek samping pada organ lain yang dapat menimbulkan perburukan keadaan pasien. Salah satu organ yang dipengaruhi oleh amiodaron adalah kelenjar tiroid, dimana dapat terjadi baik hipotiroidisme maupun tirotoksikosis. Pemantauan fungsi tiroid seharusnya dilakukan pada setiap pemberian amiodaron untuk memfasilitasi diagnosis dan terapi yang dini terhadap terjadinya disfungsi tiroid yang diinduksi amiodaron.

\section{DAFTAR PUSTAKA}

1. DiMarco JP, Gersh BJ, Opie LH. Antiarrhythmic drugs and strategy. In Opie Drug of the Heart (Sixth Edition). WB Saunders: Philadelphia, 2005; p.23642.

2. Conolly SJ. Evidence-based analysis of amiodaron efficacy and safety. Circulation. 1999;100:2025-34.

3. Adams PC, Holt DW, Morley AR, Callaghan J, Campbel RW. Amiodarone and its desethyl metabolite: tissue distribution and morphology changes during long-term therapy. Circulation. 1985;72:1064-75.

4. Harjai K, Licata A. Effects of amiodarone on thyroid function. Annals of Internal Medicine. 1997;126:63-73.

5. Loh KC. Amiodarone-induced thyroid disordes; a clinical review. Postgrad Med J. 2000;76:133-40.

6. Newman CM, Price A, Davies, Gray TA. Amiodarone and the thyroid: a practical guide to the management of thyroid dysfunction induced by amiodarone therapy. Heart. 1998;79:121-7.

7. Martino E, Bartalena L, Bogazzi F. The effect of amiodarone on the thyroid. Endocrine Reviews. 2001;22(2):240-54.

8. Hazinski MF, Cummins RO, Field JM, editors. Handbook of Emergency Cardio-vascular Care for Healthcare Providers (ACLS). American Heart Association. 2000;55.

9. Seely EW, Williams GH. The heart in endocrine disorders. In: Braunwald E, Zipes D, Libby P, editors. Heart Disease: A Textbook of Cardiovascular Medicine (Sixth Edition). Philadelphia: WB Saunders Company, 2003; p.2159- 60.
10. de Jong $M$, Docter $R$, van der Hoek $H$, Krenning E, van der Heide $D$, Quero C, et al. Different effects of amiodarone on transport of $\mathrm{T} 4$ and $\mathrm{T} 3$ into the perfused rat liver. Am $\mathrm{J}$ Physiol. 1994;266(1):E44-49.

11. Chiovato L, Martino E, Tonacchera $M$, Santini F, Lapi P, Mammoli C, et al. Studies on the in vitro cytotoxic effect of amiodarone. Endocrinology. 1994; 34: 227782.

12. Pitsiavas V, Smerdely $P$, Li M, Boyages SC. Amiodarone induces a different pattern of ultrastructural change in the thyroid to iodine excess alone in both the $\mathrm{BB} / \mathrm{W}$ rat and the Wistar rat. Eur J Endocrinol. 1997;137: 89-98.

13. Trip MD, Wiersinga WM, Plomp TA. Incidence, predictability, and pathogenesis of amiodarone-induced thyrotoxicosis and hypothyroidism. Am J Med 1991;91:507-11.

14. Thorne SA, Barnes I, Cullinan P, Somerville J. Amiodarone-associated thyroid dysfunction. Risk factors in adults with congenital heart disease. Circulation. 1999;100:149-54.

15. Bartalena L, Grasso L, Brogioni S, Aghini-Lombardi F, Braverman LE, Martino E. Serum interleukin-6 in thyrotoxicosis. J Clin Endocrinol Metab. 1994;78:423-7.

16. Bogazzi F, Bartalena L, Brogioni S, Mazzeo S, Vitti P, Burelli A, et al. Color flow Doppler sonography rapidly differentiates type I and type II amiodarone-induced thyrotoxicosis. Thyroid. 1997;7(4):541-5.

17. Wolff J. Perchlorate and the thyroid gland. Pharmacological Review. 1998;50:89106.

18. Dickstein G, Shechner C, Adawi F, Kaplan J, Baron E, Ish-Shalom S. Lithium treatment in amiodarone-induced thyrotoxicosis. Am J Med.1997;102:4548.

19. Osman F, Franklyn J, et al. Succesful treatment of amiodarone-induced thyrotoxicosis. Circulation. 2002;105:1275.

20. Bogazzi F, Bartalena $L$, Cosci, et al. Treatment of type II amiodarone-induced thyrotoxicosis by either iopanoic acid or glucocorticoids: a prospective, randomized study. J Clin Endocrinol Metab, May 2003, 88(5):1999-2002. 